\title{
ANALISIS USAHATANI JAGUNG DAN KEBERLANJUTANNYA DI PULAU KISAR KECAMATAN PULAU-PULAU TERSELATAN KABUPATEN MALUKU BARAT DAYA
}

\author{
Stephen Thenu' ${ }^{1}$, Setia Hadi ${ }^{2}$, Hermanto Siregar ${ }^{2}$, Endah Murniningtyas ${ }^{2}$
}

${ }^{1}$ Mahasiwa Program Doktoral Program Studi Perencanaan Pembangunan Wilayah dan Perdesaan Institut Pertanian Bogor, ${ }^{2}$ Pengajar pada Program Studi Perencanaan Pembangunan Wilayah dan Perdesaan Institut Pertanian Bogor.

\section{E-mail : stevethenu@gmail.com}

\begin{abstract}
ABSTRAK Jagung merupakan komoditas pangan dominan di Pulau Kisar dan menjadi sumber pangan utama masyarakat. Pengusahaannya bersifat subsistem dan tradisional untuk memenuhi kebutuhan pangan rumah tangga petani dan tidak dikomersialkan, meskipun ada yang menjualnya dalam jumlah sangat terbatas jika ada kelebihan. Sistem pertanian lahan kering menetap dengan pola tanam polikultur pada satu lahan dengan kombinasi tanaman setahun dan tahunan. Tujuan penelitian ini untuk melihat tingkat keuntungan dan kelayakan serta keberlanjutan usahatani jagung di Pulau Kisar, menggunakan Metode Survei dengan teknik Stratifikasi Random Sampling. Hasil penelitian menunjukkan bahwa biaya produksi jagung di Pulau Kisar Kecamatan PP Terselatan Kabupaten Maluku Barat Daya terdiri dari komponen biaya tetap meliputi : biaya penyusutan alat dan biaya sewa lahan, biaya variabel meliputi : biaya saprodi dan biaya tenaga kerja. Biaya variabel memberikan kontribusi terbesar terhadap biaya produksi usahatani jagung. Usahatani jagung menguntungkan dan layak diusahakan, ditunjukkan oleh besarnya rata-rata nilai pendapatan Rp.4.488.617 yang diperoleh dibandingkan dengan rata-rata biaya yang dikeluarkan petani sebesar Rp.3.755.917 serta nilai $\mathrm{BC}$ rasio sebesar 1,20. Usahatani jagung memiliki keberlanjutan secara ekonomi, ekologi dan sosial.
\end{abstract}

Kata kunci : jagung, usahatani, keuntungan, kelayakan, keberlanjutan

\section{CORN FARMING ANALYSIS AND SUSTAINABILITY IN KISAR ISLAND, DISTRICT OF THE SOUTHEST ISLAND, SOUTHWEST MALUKU REGENCY}

ABSTRACT Corn is the dominant crop commodity in Kisar Island and become staple food for the community. Corn farming are traditional and subsystems to meet farmers household food needs of farmers and not commercialized, even though they're sold in very limited numbers if there is an excess. The farming is carried out on permanent dry land by polyculture cropping pattern that is combination of annual and perrenial crops. This study aimed to examine the feasibility and profitability of corn farming in Kisar island, using survey methods with stratified random sampling technique. The results showed that the cost of corn production in Kisar Island, district of Southest Island in South West Maluku Regency is consisted of fixed cost and variable cost. The fixed cost components is including : equipment depreciation costs and land rent costs. The variable costs includes inputs costs and labor costs. Variable costs is the largest cost component for corn farming. Corn farming is profitable and viable, as indicated by the average revenue Rp. 4.488.617 compared to the average cost incurred by farmers Rp.3.755.917 and BC ratio of 1.20. Corn farming has economic, ecological, and social sustainability.

Keywords : corn, farming, Profit, feasibility, sustainability

\section{PENDAHULUAN}

Pulau Kisar sebagai salah satu sentra produksi jagung di Kecamatan Pulau-pulau Terselatan Kabupaten Maluku Barat Daya. Usahatani jagung dilakukan pada lahan kering, bersifat subsistem dan tradisional. Sistem peladangannya menetap berlokasi dipemukiman atau sekitar pemukiman penduduk dan masih mempraktekan pertanian organik. Sarana produksi yang digunakan bersifat lokal dengan penggunaan tenaga kerja dalam keluarga.

Petani sedapat mungkin mengurangi/menghindari pengeluaran biaya yang bersifat tunai, kecuali biayabiaya yang tidak dapat dihindari seperti peralatan petanian dan peralatan pascapanen (alat pengolahan hasil). Produksi jagung digunakan sebagai stok pangan dan tidak bertujuan komersial.

Sistem pertanian lahan kering bersifat sederhana mengorbankan biaya produksi tunai seminimal mungkin, sangat tergantung alam, menggunakan varietas lokal tanpa penggunaan bahan kimia, tanpa olah tanah (TOT) atau olah tanah seadanya (OTS) dan masih kuat kearifan lokalnya. Karakter pertanian seperti ini memiliki daya tarik untuk dicermati apakah kegiatan usahatani jagung yang diusahakan selama ini menguntungkan dan apakah secara ekonomis layak diusahakan jika diperhitungkan nilai dari semua faktor produksi yang digunakan dalam berusahatani.

Dalam penelitian ini semua biaya seperti: tenaga kerja, bibit, pupuk, dan obat-obatan dan biaya pemasaran ikut diperhitungkan sebagai biaya tunai (dikeluarkan petani) sekalipun secara riil tidak ada. Penghitungan ini bertujuan untuk memberikan gambaran secara ekonomis semua input dan output yang mestinya diperhitungkan seperti biaya produksi, penerimaan dan pendapatan bahkan kelayakan usahanya agar lebih relevan dibanding kondisi riil yang dapat menyebabkan bias dalam menginterpretasikan hasil analisis usahatani jagung. Penelitian ini bertujuan untuk melihat seberapa 
besar keuntungan, kelayakan dan keberlanjutan usahatani jagung di Pulau Kisar.

\section{METODE}

Penelitian berlangsung dari bulan Oktober-Desember 2012 di Kecamatan PP Terselatan pada 3 desa meliputi: Desa Abusur, Desa Lebelau dan Desa Oirata Timur. Jumlah sampel petani sebanyak 120 orang (40 orang per desa), menggunakan Metode Survei dengan teknik Multi Stage Sampling (Juanda, 2009) sebagai berikut : tahap 1, pemilihan 1 gugus pulau (GP) dari 3 buah GP, tahap 2, pemilihan 1 kecamatan dominan penghasil jagung dari 3 kecamatan, tahap 3, pemilihan 3 desa penghasil jagung dari 12 desa, tahap 4, pemilihan petani jagung menurut luas lahan usaha (sempit, sedang dan luas). Tahap 1-3 secara Purposif Sampling sedangkan tahap 4 secara Stratified Random Sampling. Untuk menganalisis biaya, penerimaan dan pendapatan usaha menggunakan Analisis Usahatani. Sedangkan keberlanjutan usahatani secara diskriptif. Analisis Usahatani memiliki formulasi sebagai berikut:

Biaya total dapat dihitung dengan menjumlahkan biaya tetap dan biaya variabel. (Boediono, 1995) :

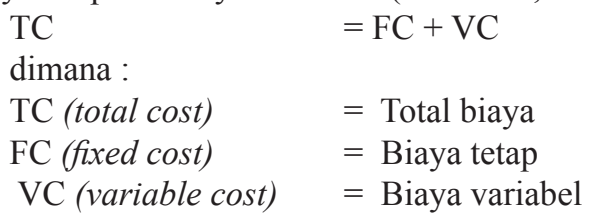

Untuk mengetahui penerimaan usahatani dapat diketahui dengan menghitung perkalian antara produksi yang diperoleh dengan harga persatuan produksi yang dapat ditulis dengan rumus sebagai berikut (Prajinanta, 1999) :

$$
\begin{aligned}
& \text { TR } \quad=\mathrm{Q} \times \mathrm{P} \\
& \text { dimana: } \\
& \mathrm{TR}: \text { total penerimaan (total revenue) } \\
& \mathrm{Q}: \text { jumlah produksi (quantity) } \\
& \mathrm{P}: \text { harga jual (price) } \\
& \mathrm{B}=\mathrm{TR}-\mathrm{TC} \\
& \text { dimana : } \\
& \mathrm{B}: \text { pendapatan bersih } \\
& \mathrm{TR}: \text { total penerimaan } \\
& \mathrm{TC}: \text { total biaya }
\end{aligned}
$$

Untuk mengetahui Kelayakan Usahatani jagung, maka digunakan analisis $\mathrm{B} / \mathrm{C}$ ratio (Bevenue Cost Ratio), dimana $\mathrm{B} / \mathrm{C}$ ratio merupakan perbandingan antara Pendapatan dengan total biaya produksi usahatani (Suratiyah, 2006). Bila BCR $>1$, maka usahatani ini layak untuk diusahakan. Sebaliknya bila BCR $<1$ maka usahatani ini tidak layak untuk dikembangkan.

Analisis Deskriptif, yaitu suatu metode yang meneliti status kelompok manusia, suatu objek, suatu set kondisi, suatu sistem pemikiran ataupun suatu kelas peristiwa pada masa sekarang (Nazir 1988). Selanjutnya (Hasan, 2004) menyatakan bahwa penelitian diskriptif bertujuan untuk memberikan gambaran mengenai suatu data, situasi atau kejadian atau memberikan gambaran hubungan antara fenomena, membuat prediksi serta implikasi suatu masalah yang ingin di pecahkan

\section{HASIL DAN PEMBAHASAN}

\subsection{Biaya Produksi Usahatani Jagung}

Biaya produksi merupakan akumulasi dari komponen biaya tetap dan biaya variabel yang digunakan dalam proses produksi pertanian (Soeharjo, 1975). Ke-

\begin{tabular}{|c|c|c|}
\hline No & Komponen Biaya Tetap & Nilai (Rp) \\
\hline 1. & Parang & 33792 \\
\hline 2. & Pacul & 14658 \\
\hline 3. & Skop & 7308 \\
\hline 4. & Garu & 3825 \\
\hline 5. & Pakwel & 10717 \\
\hline 6. & Kapak & 4867 \\
\hline 7. & Linggis & 18175 \\
\hline 8. & Hand Sprayer & 49383 \\
\hline 9. & Molen & 74010 \\
\hline 10. & Sewa Lahan & 449792 \\
\hline Total & & 910027 \\
\hline
\end{tabular}
giatan usahatani tidak terlepas dari berbagai macam penggunaan biaya dalam proses produksinya. Makin besar perolehan hasil atau semakin kecil pengeluaran biaya, maka secara umum usahatani semakin menguntungkan (Soekartawi, 1995).

\subsubsection{Biaya Tetap}

Biaya tetap adalah biaya yang besarnya tidak dipengaruhi oleh besarnya produksi (Suratiyah, 2008). Biaya tetap juga diartikan sebagai biaya yang tidak habis digunakan dalam satu kali proses produksi. Biaya ini terbentuk karena penggunaan berbagai sarana produksi pertanian diataranya peralatan pertanian. Berikut ini dapat dilihat penggunaan biaya tetap usahatani jagung pada Tabel 1 .

Sumber : Data Primer, (2012)

Tabel 1 menunjukkan bahwa rata-rata total biaya tetap sebesar Rp.910.027, terdiri dari komponen biaya penyusutan alat sebesar Rp.460.235 dan biaya sewa lahan Rp.449.792. Nilai penyusutan alat merupakan komponen biaya tertinggi dari biaya tetap sedangkan kontribusi nilai alat tertinggi adalah molen sebesar Rp.74.010. Tingginya biaya molen dibanding nilai alat lainnya disebabkan karena harga molen yang cukup besar per unit per unit Rp.500.000 (molen manual) dan Rp.2.500.000 (molen mesin) dan dimiliki petani sebagai alat pengolahan jagung.

\subsubsection{Biaya Variabel}

Biaya variabel adalah biaya yang besarnya dipengaruhi oleh besarnya produksi (Suratiyah, 2008). Biaya ini juga dikenal dengan biaya yang habis dipakai dalam satu kali proses produksi. Karena itu biaya ini merupakan salah satu komponen biaya penting dalam usahatani, karena berhubungan dengan sarana produksi yang digunakan petani. Ada beberapa komponen biaya 
variabel dalam yang praktek umumnya digunakan seperti : bibit, pupuk, obat-obatan dan tenaga kerja. Berikut ini dapat dilihat rata-rata biaya variabel usahatani jagung pada Tabel 2.

Tabel 2. Rata-Rata Biaya Variabel Usahatani Jagung di Pulau Kisar Kecamatan PP Terselatan Kabupaten Maluku Barat Daya Tahun 2012.

\begin{tabular}{lcc}
\hline No & Komponen Biaya Variabel & Nilai (Rp) \\
\hline 1. & Bibit & 414663 \\
2. & Pupuk & 1085000 \\
3. & Obat-obatan & 253308 \\
4. & Tenaga Kerja & 1092919 \\
& Total & $\mathbf{2 8 4 5 8 9 0}$ \\
\hline
\end{tabular}

Sumber : Data Primer, (2012)

Tabel 2 Menunjukkan bahwa, rata-rata total biaya variabel sebesar Rp.2.845.890, terdiri dari komponen biaya saprodi sebesar Rp.1.752.971 dan biaya tenaga kerja sebesar Rp.1.092.919. Tingginya biaya saprodi lebih disebabkan karena kebutuhan pupuk sebesar Rp.1.085.000, bibit Rp.414.663 dan obat-obatan Rp.253.308. Bibit yang dgunakan diproduksi secara lokal (varietas lokal) sedangkan pupuk biasanya menggunakan pupuk organik (bahan organik seperti: rumput, gulma, sisa tunggul jagung dan hijauan lainnya) atau pupuk kandang.

Berdasarkan akumulasi biaya tetap (fixed cost) dan biaya variabel (variable cost) maka terbentuklah biaya produksi seperti pada Tabel 3 berikut ini.

Tabel 3.Rata-rata Biaya Produksi Usahatani Jagung di Pulau Kisar Kecamatan PP Terselatan Kabupaten Maluku Barat Daya Tahun 2012.

\begin{tabular}{lcc}
\hline No & Komponen Biaya & Nilai (Rp) \\
\hline 1. & Biaya Tetap & 910027 \\
2. & Biaya Variabel & 2845890 \\
& Biaya produksi & $\mathbf{3 7 5 5 9 1 7}$ \\
\hline
\end{tabular}

Sumber : Data Primer, (2012)

Tabel 3 menunjukkan bahwa rata-rata total biaya produksi usahatani jagung sebesar Rp.3.755.917, terdiri dari komponen biaya variabel sebesar Rp.2.845.890 dan biaya tetap Rp.910.027. Biaya variabel memberikan kontribusi terbesar terhadap biaya produksi, karena kebutuhan sarana produksi yang digunakan dalam proses produksi dan tenaga kerja yang digunakan.

\subsection{Penerimaan Usahatani Jagung}

Penerimaan adalah perkalian antara hasil produksi dan harga jual. Penerimaan petani tergantung dari besar kecilnya produksi yang dihasilkan dan harga jual dari komoditi tersebut di pasar (Suherman dkk, 2002). Rata-rata penerimaan usahatani jagung di Pulau Kisar ditampilkan pada Tabel 4 berikut ini.
Tabel 4. Rata-Rata Produksi, Harga Jual dan Penerimaan Usahatani Jagung di Pulau Kisar Kecamatan PP Terselatan Kabupaten Maluku Barat Daya Tahun 2012.

\begin{tabular}{lcc}
\hline No & Uraian & Nilai (Rp) \\
\hline 1. & Produksi & 1457 \\
2. & Harga Jual & 5650 \\
& Penerimaan & $\mathbf{8 2 4 4 5 3 4}$ \\
\hline
\end{tabular}

Sumber : Data Primer, (2012)

Tabel 4 menunjukkan bahwa rata-rata penerimaan usahatani jagung sebesar Rp.8.244.534 dengan ratarata produksi (kering pipil) $1457 \mathrm{~kg}$ dan harga jual Rp.5.650. Harga jual yang berlaku di lokasi penelitian berkisar antara Rp.5000-6500/kg. Artinya harga jagung kering pipil bisa berfluktuasi sesuai musim tanam yang berlaku di wilayah penelitian (musim tanam barat bulan Oktober-Februari dan musim tanam timur bulan AprilAgustus). Biasanya pada musim tanam timur harga jagung cenderung turun, hal ini disebabkan karena pada musim ini produksi jagung cukup tinggi karena didukung oleh curah hujan yang baik. Hal ini sejalan dengan pendapat (George et al. 2006), menyatakan bahwa Usahatani subsisten rentan terhadap guncangan harga pasar sebagai akibat dari fluktuasi produksi secara musiman.

\subsection{Pendapatan Usahatani Jagung}

Berhasilnya suatu usahatani dapat dilihat dari tingkat pendapatan yang diterima perani dari pengelolaan usahataninya. Atau dengan kata lain, besar kecilnya keuntungan

tergantung pada besar kecilnya penerimaan total dan biaya produksi total yang dikeluarkan (Sarasutha, 2002). Tabel 5 berikut ini tentang rata-rata pendapatan usahatani jagung.

Tabel 5. Rata-Rata Penerimaan, Biaya Produksi dan Pendapatan Usahatani Jagung di Pulau Kisar Kecamatan PP Terselatan Kabupaten Maluku Barat Daya Tahun 2012.

\begin{tabular}{lcc}
\hline No & Uraian & Nilai (Rp) \\
\hline 1. & Penerimaan & 8244534 \\
2. & Biaya Produksi & $\mathbf{3 7 5 5 9 1 7}$ \\
& Pendapatan & $\mathbf{4 4 8 8 6 1 7}$ \\
\hline
\end{tabular}

Sumber : Data Primer, (2012)

Tabel 5 menunjukkan bahwa pendapatan usahatani jagung di Pulau Kisar sebesar Rp.4.488.617 diperoleh dari penerimaan sebesar Rp.8.244.534 di kurangi dengan biaya produksi sebesar Rp.3.755.917. Hasil ini menunjukkan bahwa petani memperoleh keuntungan dari usahatani jagung, karena penerimaan lebih besar dari biaya yang dikeluarkan selama proses produksi berlangsung.

\subsection{Analisis Kelayakan Usahatani}

Nilai Benefit Cost Ratio (BCR) adalah perbandingan antara pendapatan yang diperoleh dengan besarnya 
biaya yang dikeluarkan petani selama proses produksi, dan nilai tersebut digunakan untuk menganalisis kelayakan usahatani jagung (Nugroho, 2008). Rata-rata nilai $\mathrm{B} / \mathrm{C}$ rasio dari usahatani jagung ditampilkan pada Tabel 6 berikut ini.

Tabel 6. Rata-Rata Nilai BC Rasio Usahatani Jagung di Pulau Kisar Kecamatan PP Terselatan Kabupaten Maluku Barat Daya Tahun 2012.

\begin{tabular}{llc}
\hline No & Uraian & Nilai (Rp) \\
\hline 1. & Pendapatan & 4488617 \\
2. & Biaya Produksi & 3755917 \\
\hline & B/C Rasio & $\mathbf{1 , 2 0}$ \\
\hline
\end{tabular}

Sumber : Data Primer, (2012)

Tabel 6 menunjukkan bahwa nilai Benefit Cost Rasio (BCR) usahatani jagung besar dari satu (BCR> 1). Ini menggambarkan bahwa usahatani jagung di Pulau Kisar menguntungkan dan layak diusahakan. Nilai B/C rasio sebesar 1,20 menunjukkan bahwa biaya yang dikeluarkan sebesar Rp.3.755.917 akan memberikan keuntungan sebesar 1,2 kali lipat dari biaya yang dikorbankan.

\section{Keberlanjutan Usahatani}

Keberlanjutan mengacu pada pemenuhan kebutuhan generasi sekarang tanpa menggangu generasi mendatang. Keberlanjutan usahatani mencakup aspek ekonomi, ekologi dan sosial. (Brundtland, 1987, Hediger, 1998)

Aspek ekonomi yaitu bagaimana menghasilkan pendapatan dari proses produksi pertanian (jagung) tanpa mengorbankan lingkungan atau meminimalisir kerusakan lingkungan akibataktivitas pertanian sehingga pendapatan petani berkelanjutan. Aktivitas usahatani jagung berlangsung disekitar rumah/pemukiman petani dengan pola lahan kering menetap. Proses penyiapan lahan secara alami tanpa membakar/menebang tetapi melalui proses pembersihan dan pelapukan terhadap hijauan, ranting, serasah dan sampah organik lainnya yang bakal menjadi bahan organik untuk kesuburan tanah. Sistem pengolahan tanah dengan pencangkulan seadanya bahkan TOT, tanpa penggunaan pupuk dan obat-obatan kimia maka usahatani jagung di Pulau Kisar sangat aman bagi lingkungan. Jagung sebagai pangan pokok digunakan sebagai stok pangan utama disamping umbian dan kacang-kacangan. Untuk mempertahankan keberlanjutan pangan dan kehidupan rumah tangga petani, maka petani biasa memiliki sumber pendapatan non jagung seperti, ternak (unggas dan ternak : babi, kambing, domba), penyadapan nira (sopi dan gula merah), hasil jeruk, kios, tukang, kiriman dan lain-lain. Karena memiliki berbagai sumber penghasilan inilah maka terjadi subsidi silang diantara berbagai sumber pendapatan sehingga jagung tetap menjadi stok pengaman pangan petani. Sebaliknya dengan keberhasilan usahatani jagung, ikut membantu mengurangi beban biaya yang semestinya dikeluarkan petani untuk memenuhi kebutuhan pangan.
Aspek ekologi menyangkut kapasitas ekosistem lingkungan berhubungan ketersediaan sumberdaya alam yang dapat dipertahankan untuk menjamin kehidupan generasi kini dan generasi mendatang. Aspek ekologi juga memperhitungkan batas limit (tingkat kritis) yaitu kelenturan ekosistem dan pemenuhan kebutuhan dasar manusia (Hediger, 1998). Kisar adalah pulau kecil dengan luas wilayah $67,52 \mathrm{~km}^{2}$ memiliki tingkat kekeringan wilayah yang cukup ekstrim dengan curah hujan tahunan 900-1200 mm. Wilayah ini dipengaruhi oleh 2 musim yaitu musim barat dan timur, sehingga akativitas pertanian sangat tergantung alam. Musim timur ditandai oleh musim penghujan dan peningkatan aktivitas angin dan gelombang laut sehingga wilayah ini praktis hampir tidak terakses. Petani memiliki berbagai kearifan lokal yang tinggi menyikapi kondisi wilayah yang ekstrim. Karena itu penerapan pertanian organik bersifat lokal dan subsisten serta pola tanam, panen dan pasca panen yang apik dan unik merupakan strategi agar eksis dan dapat memenuhi kecukupan pangan rumah tangga. Hal ini senada dengan Pujiharti, et a.l 2008, Syarifuddin, 2010) menyatakan bahwa pengembangan sistem usahatani jagung dengan inovasi teknologi berbasis sumberdaya lokal antara lain memodifikasi pertanaman, memanipulasi lingkungan dan sistem tanam serta menerapkan inovasi teknologi secara spesifik sehingga usahatani lebih optimal. Pulau ini memiliki kelebihan dibanding kawasan lain di Kabupaten Maluku Barat Daya yakni bercocok tanam jagung dua musim dalam setahun sedangkan wilayah lainnya hanya satu musim tanam. Hal ini dapat terjadi karena tingginya etos kerja petani dan memiliki kearifan lokal yang baik terhadap keberlanjuan lingkungan.

Aspek sosial merujuk pada konsep keberlanjutan socio-budaya yang menghasilkan kestabilan sosial dan budaya. Hal ini sesuai dengan defenisi sustinable development (WCED, 1987), dalam (Hediger, 1998) yang pada pokoknya didasarkan pada prinsip etika “ keadilan sosial (social justice). Sosial budaya memiliki peran sentral terutama kontribusinya dalam nilainilai budaya dan kelembagaan yang tertanam dalam masyarakat ditunjukkan dengan adanya berbagai bentuk kelembagaan seperti : mata rumah, soa, sasi, lumbung pangan, lutur, masohi dan kelembagaan lainnya. Setiap kelembagaan memiliki peran mulai dari aspek pemerintahan desa, sistem adat, interaksi sosial, kerjasama, petanian dan ketahanan pangan hingga pelestarian lingkungan. Nilai-nilai ini merupakan kearifan lokal yang hidup dan bersinergi dalam kehidupan masyarakat termasuk dalam berusahatani sehingga mampu memberikan rasa aman dan rasa keadilan bagi masyarakat dalam pemanfaatan sumberdaya. Salah satunya adalah sasi atau sistem sasi, merupakan pranata sosial yang mengandung kelenturan yang mengatur tentang larangan untuk mengambil dan kebolehan warga masyarakat dalam mengelola 
sumberdaya alam dan lingkungan hidup dalam jangka waktu tertentu. Sistem sasi memiliki tujuan antara lain:

(1) menjaga ketertiban dan mencegah perusakan sumberdaya alam dan lingkungan hidup secara kolektif,

(2) membentuk pola pikir dan tingkahlaku masyarakat menjadi masyarakat berwawasan lingkungan,

(3) perlindungan hak perorangan/warga, sesuai ketentuan waktu untuk mendapatkan hasil yang lebih optimal

(4) membangun etika masyarakat yang berkeadilan sosial.

Sistem sasi bersifat fleksibel dan bisa diterapkan pada berbagai aspek kehidupan yang berhubungan dengan pemeliharaan dan pemanfaatan sumber daya (khusus SDA). Sumberdaya yang disasi dapat berupa : kebun, hasil hutan dan hasil laut sebagai klaim individu, klaim keluarga dan masyarakat. Lembaga yang terlibat dalam mengatur sistem sasi adalah lembaga adat dan lembaga keagamaan (Gereja). Kedua lembaga ini selain melakukan sasi juga mengawasi bersama dengan masyarakat.

\section{SIMPULAN}

Biaya produksi jagung di Pulau Kisar Kecamatan PP Terselatan Kabupaten Maluku Barat Daya terdiri dari komponen biaya tetap (fixed cost) dan biaya variabel (variable cost). Biaya tetap meliputi : biaya penyusutan alat dan biaya sewa lahan dan biaya variabel meliputi : biaya saprodi : (bibit, pupuk, obat-obatan) dan biaya tenaga kerja. Biaya variabel memberikan kontribusi terbesar terhadap biaya produksi usahatani jagung.

Hasil analisis biaya, penerimaan dan pendapatan usahatani menunjukkan bahwa usahatani jagung menguntungkan dengan nilai pendapatan sebesar Rp.4.488.617 merupakan selisih antara penerimaan usahatani sebesar Rp.8.244.534 dengan biaya produksi sebesar Rp. 3.755.917

Usahatani jagung di Pulau Kisar layak diusahakan karena nilai BCR (benefit cost rasio) lebih besar dari satu $(\mathrm{BCR}>1)$. Besarnya nilai $\mathrm{BC}$ rasio sebesar 1,20 menggambarkan bahwa usahatani jagung akan memperoleh keuntungan sebesar 1,2 kali lipat dari korbanan biaya produksi sebesar Rp.3.755.917.

Usahatani jagung di Pulau Kisar memiliki keberlanjutan secara ekonomi, ekologi dan sosial.

Petani perlu melakukan perencanaan produksi seperti efisiensi penggunaan saprodi, antisipasi waktu tanam berhubungan dengan musim tanam dan curah hujan serta keseimbangan lingkungan agar tetap terpelihara keberlanjutan sistem usahatani jagung di Pulau Kisar.

\section{DAFTAR PUSTAKA}

Boediono, 1995. Ekonomi Mikro Edisi kedua. Penerbit BPFE : Yogyakarta.
Brundtland,1987http://en.wikipedia.org/wiki/Brundtland Commission.

George A.D, Steve B. and Taylor. J.E. 2006. Subsistence Response to Market Shocks. American Journal of Agricultural Economics. Vol 88. No. 2. 2006. (p:279-291).

Hasan, I. 2004. Analisis Data Penelitian dengan Statistik. Penerbit Bumi Aksara. Jakarta.

Hediger, 1998. Sustainable Development And Social Welfare. Agricultur Economics, Swiss federal Institute of Technology, ETH- Zentrum (SOL), 8092 Zurich, Switzerland 2-nd October 1998.

Juanda, B. 2009 Metodologi Penelitian Ekonomi dan Bisnis. Edisi kedua IPB Press.

Nazir, M. 1988. Metode Penelitian. Ghalia Indonesia. Jakarta.

Nugroho, R. A. 2008. Analisis Usahatani Tanaman Kedelai (Glycine max (L) merril) KELAS Foundation Seed (FS)

untuk Menghasilkan Benih Bersertifikat. Skripsi. Jurusan Agribisnis Pertanian. UGM : Yogyakarta. Tidak Dipublikasikan.

Prajinanta, 1999. Agribisnis Cabai Hibrida. Penebar Swadaya : Jakarta

Pujiharti, Y., O. Haridjaja, Eriyatno, dan IW.Rusastra. 2008. Model Pengelolaan Lahan Kering Berkelanjutan pada Sistem Agribisnis Jagung. Jurnal Tanah Tropika 13(1) : 67-7 6.

Sarasutha, IG.P. 2002. Kinerja usahatani dan pemasaran jagung di sentra produksi. Jurnal Penelitian dan Pengembangan Pertanian 21(2): 39-47.

Soeharjo, 1975. Sendi - sendi Pokok Usahatani. Departemen Sosial Ekonomi Fakultas Pertanian Institut Pertanian : Bogor

Soekartawi, 1995. Analisis Usahatani. Penerbit Universitas Indonesia : Jakarta

Suherman, O., Burhanuddin, Faesal, M. Dahlan, dan F. Kasim (2002). Pengembangan Jagung Unggul Nasional Bersari Bebas dan Hibrida : Risalah Penelitian Jagung dan Serealia Lain.

Suratiyah, K. 2006. Ilmu Usahatani. Penerbit Swadaya : Jakarta.

Syarfuddin, 2010. Modifikasi Sistem pertanaman Jagung dan Pengolahan Brangkasan untuk meningkatkan Pendapatan Petani di Lahan Kering. Balai Pengkajian Teknologi Pertanian Sulawesi Tengah. Jurnal Litbang Pertanian 30 (1), 2011 